\title{
Mitochondria in cardiac hypertrophy and heart failure
}

\author{
Mariana G. Rosca ${ }^{1}$, Bernard Tandler ${ }^{2}$, and Charles L. Hoppel ${ }^{1}$ \\ ${ }^{1}$ Center for Mitochondrial Diseases and Departments of Medicine and Pharmacology, School of \\ Medicine, Case Western Reserve University, Cleveland, Ohio \\ ${ }^{2}$ School of Dental Medicine, Case Western Reserve University, Cleveland, Ohio
}

\begin{abstract}
Heart failure (HF) frequently is the unfavorable outcome of pathological heart hypertrophy. In contrast to physiological cardiac hypertrophy, which occurs in response to exercise and leads to full adaptation of contractility to the increased wall stress, pathological hypertrophy occurs in response to volume or pressure overload, ultimately leading to contractile dysfunction and HF. Because cardiac hypertrophy impairs the relationship between ATP demand and production, mitochondrial bioenergetics must keep up with the cardiac hypertrophic phenotype. We review data regarding the mitochondrial proteomic and energetic remodeling in cardiac hypertrophy, as well as the temporal and causal relationship between mitochondrial failure to match the increased energy demand and progression to cardiac decompensation. We suggest that the maladaptive effect of sustained neuroendocrine signals on mitochondria leads to bioenergetic fading which contributes to the progression from cardiac hypertrophy to failure.
\end{abstract}

\section{Keywords}

heart failure; cardiac hypertrophy; mitochondria; oxidative phsophorylation

\section{Introduction}

Heart Failure (HF) is a major and growing public health concern, and a leading cause of morbidity and mortality in industrialized countries worldwide. In this country at least $2 \%$ of the population suffers from this affliction with an annual mortality rate that range from $10 \%$ to $20 \%$ depending on the severity $[1,2]$. Because of its high prevalence, $\$ 28$ billion are expended annually in the US for treatment [3]. The major causes of HF include myocardial infarction, arterial hypertension, cardiomyopathy, and valvular heart diseases.

Heart failure frequently is the unfavorable outcome of pathological heart hypertrophy. Cardiac hypertrophy is the growth response of the heart to an increase in mechanical stress induced by either extrinsic factors such as increased pressure or volume overload in hypertension and valvular diseases, or intrinsic factors such as ischemia-induced cardiac

(C) 2012 Elsevier Ltd. All rights reserved.

Address for correspondence: Charles L. Hoppel, M.D. Case Western Reserve University, School of Medicine, Department of Pharmacology, 10900 Euclid Avenue, Cleveland, OH 44106-4981, Tel: 216368 3147, Fax: 216368 5162, charles.hoppel@ case.edu. Publisher's Disclaimer: This is a PDF file of an unedited manuscript that has been accepted for publication. As a service to our customers we are providing this early version of the manuscript. The manuscript will undergo copyediting, typesetting, and review of the resulting proof before it is published in its final citable form. Please note that during the production process errors may be discovered which could affect the content, and all legal disclaimers that apply to the journal pertain.

DISCLOSURE

The authors have nothing to declare. 
remodeling or hypertrophic cardiomyopathy. By means of hypertrophy, the heart normalizes the increase in wall tension and sustains cardiac output in the face of stress. During the compensated phase of pathological hypertrophy the hypertrophic response matches the increased workload, so there is no negative impact on the heart contractile performance. In contrast, the decompensated stage of pathological hypertrophy follows this initial phase of compensation and leads to contractile dysfunction and HF. In comparison with pathological hypertrophy, physiological hypertrophy develops in response to either isometric, i.e., weightlifting, or isotonic, i.e., cycling, physical exercise, which leads to intermittent pressure and volume overload, respectively, and does not lead to HF. Our topic will deal exclusively with pathological hypertrophy and its decompensation to HF.

Energy supply in the form of ATP is mandatory to sustain cardiac contractile and relaxation functions. The heart is the greatest oxygen-consuming organ in the body, with no excess capacity for ATP production versus utilization. Ninety percent of this requirement is met by mitochondrial oxidative phosphorylation that is finely adjusted to energy need. In addition to providing energy for cardiac contraction and relaxation, mitochondria generate reactive oxygen species (ROS) that mediate the inotropic and hypertrophic effects of sympathetic and renin-angiotensin-aldoesteron systems [4,5]. Cardiac hypertrophic adaptation is accomplished by the induction of a fetal genetic program followed by changes in cellular phenotype, leading to enhanced protein synthesis and increased cardiomyocyte size. Mitochondrial oxidative capacity is reported to be either preserved or even enhanced in cardiac hypertrophy $[6,7]$. In contrast, in both human subjects and experimental models of HF mitochondrial function is decreased [8-10].

This review focuses on the interaction between the neuroendocrine response and signaling pathways that contribute to changes in mitochondrial biogenesis and function in the compensated versus decompensated phases of pathological hypertrophy. We evaluate the decrease in mitochondrial bioenergetics as a potential factor responsible for the transition from the compensated stage of cardiac hypertrophy to HF.

\section{A. Cardiac mitochondria through the transition from cardiac hypertrophy to failure}

\section{Mitochondrial biogenesis}

Primary mitochondrial cardiomyopathies in human subjects lead to mitochondrial proliferation in cardiomyocytes [11]. Mitochondrial proliferation also occurs in murine models of cardiomyopathies associated with ablation of either the adenine nucleotide translocase 1 [12], frataxin [13], Mn-SOD [14], or mitochondrial transcription factor A (TFAM) [15]. In TFAM knockout mice-with early metabolic switch towards decreased fat and increased glucose oxidation, and progressive cardiomyopathy-there is a decrease in mtDNA replication and transcription, as well as impaired mitochondrial electron transport chain (ETC) associated with increased mitochondrial mass [15]. Despite the increase in the number of mitochondria, the mitochondrial defect is not compensated for, as shown by severe ATP depletion.

In acquired cardiomyopathy, the cardiomyocyte hypertrophy phase, in which there is an increase in mitochondrial biogenesis, is essential to delay cardiac decompensation induced by pressure overload. If the hypertrophic phase is bypassed - as in mice deficient in mammalian target of rapamycin (mTOR) that have been challenged by aortic constrictiona severe and rapidly progressive dilated cardiomyopathy occurs [16].

During compensated cardiac hypertrophy mitochondrial density seems to match the energy demand of the hypertrophic cardiomyocyte but decreases during cardiac decompensation. In 
homogenates of cardiac tissue derived from pressure overload-hypertrophied hearts the activities of the mitochondrial marker enzymes citrate synthase and cytochrome c oxidase, as well as the expression of oxidative phosphorylation genes, were unchanged $[17,18]$. Dai et al. recently showed that angiotensin II and experimental mtDNA deletions lead to upregulation of mitochondrial biogenesis signaling in cardiac hypertrophy, and the latter is completely blunted when the disease progresses to HF [5]. Garnier et al. found that HF induced by aortic banding in rats is associated with downregulation of all main transcription factors of mitochondrial biogenesis [19]. In their study, the amount of PGC1a mRNA is linear with the expression of both the mitochondrial marker enzyme, citrate synthase, and two protein subunits of cytochrome $c$ oxidase encoded by either mitochondrial or nuclear DNA.

The status of mitochondrial biogenesis in human HF has not been clearly defined. The amount of TFAM, mtDNA, and mRNA for all mitochondrial-encoded subunits of the ETC is normal in explanted failing heart when compared with donor hearts, suggesting that there is no decline in mitochondrial gene expression [20]. However, retrospective analysis of drug therapy before transplantation identified beta-blockers that may have been provided protection against this disturbance.

In summary, the data support a reciprocal relationship between alterations in mitochondrial biogenesis and cardiac pathology.

\section{Mitochondrial oxidative capacity}

\section{Defects in individual components of the ETC and phosphorylation apparatus}

in HF-Very little data exist regarding the activity of individual components of the mitochondrial ETC during the period of compensated cardiac hypertrophy. Griffiths et al. reported a decrease in complex I and II activities without a change in complex amounts in the early pressure-overload cardiac hypertrophy induced by thoracic aortic banding in neonatal rabbits [21]. In mice, transverse aortic constriction leads to an increase in some nuclear-encoded enzymes of the Krebs cycle and subunits of complex I, III, IV, and V of the ETC [22]. Similar results were obtained in aortic constriction in rats [23] and in oldspontaneously hypertensive rats with left ventricle dysfunction [24]. However, these studies do not provide information about either the consequence of this proteomic remodeling on the activities of individual ETC complexes or the consequence of ETC changes on oxidative phosphorylation and energy generation. In contrast to these studies, we attempted to link the activities of ETC complexes to the integrated mitochondrial function, and measured both the individual activities of ETC complexes and oxidative phosphorylation rates in freshlyisolated cardiac mitochondria from canine hearts. In a moderately severe stage of microembolism-induced HF, we found that the individual mitochondrial ETC complexes were unchanged whereas mitochondrial oxidative phosphorylation was severely decreased. The defect resides in the assembly of ETC complexes in respirasomes that support oxidative phosphorylation [8].

Most groups perform the measurement of ETC complex activities on homogenates or mitochondrial particles prepared from frozen-thawed cardiac muscle tissue of hearts already in the decompensated stage. Variable mitochondrial defects have been reported to occur in the ETC complexes and components of the phosphorylation apparatus in heart mitochondria in HF of different etiologies (Table 1), and were briefly evaluated by us in recent reviews $[25,26]$. Using the pacing-induced model in dogs as a model of human dilated cardiomyopathy, Marin-Garcia et al. reported a severe decrease in the activity of complex III in frozen-thawed cardiac tissue homogenates [27-29]. A decrease in complex III activity also was observed in cardiac tissue homogenates from human subjects undergoing cardiac transplantation who had either idiopathic or ischemic dilated cardiomyopathy [30]. Based on 
studies of mitochondrial particles isolated from frozen cardiac tissues, Ide et al. reported a decrease in complex I activity in pacing-induced canine HF [31], whereas in human dilated cardiomyopathy Buchwald et al. found defects in complexes III and IV [32]. A complex IV defect was reported in an experimental model of pressure overload HF, the spontaneous arterial hypertension in rats, when measured in frozen-thawed isolated cardiac mitochondria [33]. In human subjects, the decrease in complex IV activity measured in freshly-isolated heart mitochondria is correlated with the ejection fraction of the affected hearts [34].

Alterations in the components of the phosphorylation apparatus characterized by decreased amount and activity of ATP synthase were reported to occur in pig cardiac tissue with ischemic HF induced by left circumflex coronary artery ligation [35], as well as in dogs [36] and human patients with dilated cardiomyopathy [37]. Complex V activity is severely decreased when measured in cardiac muscle frozen-thawed homogenates from dogs with pacing-induced HF [27-29]. Schultheiss et al. found a decrease in the ANT transport capacity in explanted cardiac tissue of patients with dilated cardiomyopathy [38] associated with an increase in the amount of the total ANT protein [39] and a shift in the ANT isoform expression characterized by an increase of the ANT1 and a decrease in ANT2 [40], which restricts ANT function [41]. Altered ANT isoform expression also was found in endomyocardial biopsies during early stages of dilated cardiomyopathy, suggesting that the ANT defect may cause the energy deficit and progression of HF. In inflammatory cardiac diseases there is also an ANT shift, but this does not occur in ischemic, valvular, and hypertrophic cardiomyopathy [40]. In contrast to human dilated cardiomyopathy, in the canine pacing-induced HF model we found a decrease in complex I-III activity expressed as rotenone-sensitive NADH cytochrome $\mathrm{c}$ reductase, using fresh tissue homogenate prepared from both septum and lateral wall of the left ventricle. In contrast, complex I and III activities in the corresponding SSM and IFM (unpublished observations) are unchanged, suggesting that the mitochondrial isolation procedure might result in the loss of an extramitochondrial inhibitor factor, such as cytosolic kinases, that may be responsible for the depressed mitochondrial complex I-III activity observed in cardiac tissue. These data highlight the importance of measuring ETC complex activities in both tissue homogenates and isolated mitochondria.

In summary, there is a broad variability in reported mitochondrial defects in the failing heart. The causal link between the reported defects and the decrease in mitochondrial oxidative phosphorylation has not been defined in most of these studies. The assessment of activities of the individual ETC complexes or components of the phosphorylation apparatus cannot detect defects in integrated mitochondrial function where oxidation of substrates is coupled with electron transport and consumption of ADP to synthesize ATP. ETC defects may not lead to a decrease in mitochondrial oxidative phosphorylation and energy deficit. The increase in oxidative capacity when the limitation by the phosphorylation system is released experimentally by an uncoupler [42] suggests that there is an apparent excess in ETC complex activity relative to the phosphorylation apparatus and the oxidative phosphorylation requirement $[43,44]$. The sites of control of respiration in normal heart isolated mitochondria are located at complex I in the ETC [45] and at adenine nucleotide translocase and complex V in the phosphorylation apparatus [46]. In human heart, the phosphorylation system exerts a strong limitation on oxidative phosphorylation [47]. In contrast, the site of oxidative phosphorylation control in intact cells is located in complex IV [48] due to the ATP-allosteric inhibition of the complex [49]. Therefore, the measurement of ETC complex activities must be complemented with the assay for oxidative phosphorylation in order to establish a causal link between the reported ETC defects and decreased mitochondrial function. 


\section{Abnormalities in the integrated mitochondrial function and respirasomes-}

Hypertrophic human hearts exhibit an increase in mitochondrial respiratory activity [7].

Similarly, rabbit cardiac mitochondria show increased oxidative phosphorylation rates during early stage of hypertrophy followed by decreased rates upon progression to HF induced by aortic constriction in [50]. Doenst et al. report that the pattern of substrate oxidation predicts the progression of HF in rats with aortic arch constriction [6]. The oxidation of the complex I substrate, glutamate, has a biphasic pattern with an early increase followed by a decline coinciding with the drop in contractility and ejection fraction.

Decreased mitochondrial fatty acid oxidation precedes the decline in contractility. Upon the addition of an uncoupler, oxygen consumption increases in similar fashion in catecholamine-perfused normal and pressure-overload hypertrophied swine hearts but not in failing hearts, indicating that mitochondrial oxidative capacity (proximal to the phosphorylation apparatus) is preserved in compensatory hypertrophy and is decreased in HF [51].

Decreased state 3 respiratory rates (ADP-dependent) were found when oxygen consumption was measured in the presence of glutamate+malate in saponin-permeabilized cardiac fibers isolated from rat [19, 52], dog [9], and human [10] hearts with dilated cardiomyopathy as well as in pressure overload- and ischemic-induced HF. Similarly, the failing human heart experiences early defects in complex I-linked respiration and fatty acid oxidation, as well as in the phosphorylation apparatus [47].

Respiratory studies using cardiac fibers do not differentiate between the two distinct mitochondrial populations, SSM and IFM $[53,54]$ which may be differentially affected by HF. For example, Lindenmayer et al. reported a $40 \%$ decrease in glutamate- and succinatesupported state 3 respiratory rates in heart mitochondria isolated from guinea pigs with congestive HF induced by stenosis of the ascending aorta [55]. The experimental protocol reveals that these authors isolated in fact cardiac SSM. Sordahl et al. reported that a similar model of HF in rabbits was associated with only $22 \%$ decrease in glutamate+malate- and succinate- supported state 3 respiratory rates of heart mitochondria [50]. We believe that the difference in the degree of mitochondrial defect is due to the fact that each study of the foregoing reports reports the mitochondrial respiratory properties of different cardiac mitochondrial populations. Lindenmayer et al. more than likely studied SSM, since their experimental protocol used the polytron, whereas Sordahl et al. studied a mix of the two types of mitochondria, SSM and IFM, because the isolation protocol included a protease complemented by polytron homogenization. The latter approach partially diminished the severity of the initially observed defect. These data indicate that the two mitochondrial populations are differentially affected by HF, with IFM being less affected.

Our approach to the integrated function of the ETC coupled to ATP synthesis, membrane transport, dehydrogenase activities, and the structural integrity of the mitochondria utilizes the analysis of oxidative phosphorylation in freshly-isolated cardiac SSM and IFM. The investigation of the two metabolically and structurally distinct populations of mitochondria [56] led us to reconcile the disparate finding regarding the oxidative properties of heart mitochondria in dystrophic cardiomyopathy in hamsters [57, 58]. A decrease in respiratory state 3 rates with complex I or II substrates was present only in IFM. The decrease in state 3 respiratory rates was reversed by the addition of an uncoupler, indicating that the defect resides in the phosphorylation apparatus. The control of oxygen consumption by phosphorylation ("coupling") as well as the efficiency of oxidative phosphorylation was preserved. The defect in IFM was progressive and paralleled the degree of peripheral congestion [56]. 
In a follow-up to the work performed by Sharov et al. on oxidative phosphorylation in saponin-permeabilized cardiac fibers in canine intracoronary microembolization-induced $\mathrm{HF}$ of moderate severity [9], we performed a study of respiratory properties of the two populations of freshly-isolated heart mitochondria [8]. Both populations of heart mitochondria were equally affected in this model of HF, with a decrease in respiratory rates with substrates donating electrons at complex I, II, III, and IV caused by a decreased amount of the $\mathrm{I} / \mathrm{III} \mathrm{I}_{2} / \mathrm{IV}$ respirasome [8]. The occurrence of mitochondrial dysfunction and decreased supercomplex organization at an early stage of the disease leads to the hypothesis that the decline in bioenergetics contributes to the progression of HF.

Rapid ventricular pacing in dogs mimics human idiopathic dilated cardiomyopathy. We found that oxidative phosphorylation is decreased at complex III in both SSM and IFM isolated from the cardiac septum. The oxidation of both complex I and II substrates is unchanged, indicating that the isolated decrease in complex III-supported respiration does not play a relevant pathophysiological role in decreasing mitochondrial respiratory properties isolated from cardiac septum. In contrast, SSM from the left ventricle lateral wall are unaffected; IFM show a decreased oxidative phosphorylation at complexes I, II, and III that is partially relieved by the uncoupler, dinitrophenol, with complex II and III substrates. These data suggest a complex alteration of cardiac IFM from left ventricle wall in this type of HF involving the components of the phorphorylation apparatus and possibly the organization in supercomplexes (unpublished observation). The data also indicate a regional distribution of mitochondrial defects with the left ventricle lateral wall being the major target.

We conclude that studies on mitochondrial function in freshly-isolated cardiac SSM and IFM yield a more accurate picture of the consequence of the ETC complex changes in cardiac hypertrophy and HF. Also, the assessment of integrated mitochondrial function as oxidative phosphorylation is the only assay able to localize the modification within the oxidation or phosphorylation apparatus, and should direct further investigation towards indentifying the specific site of alteration. By investigating mitochondrial oxidative phosphorylation over the course of the disease, it is concluded that compensatory cardiac hypertrophy is associated with an increase in cardiac mitochondrial oxidative capacity, and that in congestive HF mitochondria exhibit pronounced dysfunction.

\section{Does mitochondrial bioenergetic failure cause the progression of cardiac hypertrophy to cardiac failure?-Both cardiac systolic and diastolic function are} dependent on mitochondrial-generated ATP, suggesting that mitochondrial bioenergetic decline contributes to the progression of HF. Normal myocardium has the ability to switch between glucose and fatty acids as fuel sources (metabolic flexibility). The catabolism of fatty acids provide up to $90 \%$ of the ATP in the healthy heart [8]. Most clinical [9-11] and experimental [12-14] studies find that both pathological hypertrophy and heart failure are accompanied by metabolic inflexibility characterized by a decrease in fatty acid oxidation. Does mitochondrial remodeling induce this metabolic remodeling? Studies performed on pathological hypertrophied hearts show no change in the expression of mitochondrial fatty acid transport and oxidation enzymes [15], whereas others report a decrease in their expression, which would predict a decrease in mitochondrial fatty acid oxidation [16]. The decrease in mitochondrial fatty acid oxidation is reported to predict the onset of contractile dysfunction in pressure overload-challenged rats [17]. Overt heart failure is associated with a severe decrease in fatty acid oxidation [18]. In terms of ATP production, one molecule of palmitate yields far more ATP than does glucose. Therefore, to maintain a constant ATP content, a pronounced increase in glucose oxidation must accompany a relatively modest decrease in fatty acid oxidation. Most studies report that the decrease in FA oxidation is not compensated for by an increase in glucose oxidation [13, 19]. The metabolic remodeling in 
heart failure is the focus of numerous extensive reviews [20,21]. The general conclusion is that there is no true metabolic switch characterized by a decrease in fat oxidation and a corresponding increase in glucose oxidation, and that the failing heart is an energycompromised organ.

Transverse aortic constriction in rats leads to HF that occurs in three different stages, such as compensated hypertrophy, HF with diastolic dysfunction and preserved ejection fraction, and HF with reduced ejection fraction $[6,23,59]$. In this experimental model, mitochondrial oxidative capacity is increased or preserved during the first two stages, and is decreased during the development of systolic dysfunction, suggesting that diastolic dysfunction is independent of mitochondrial function whereas mitochondrial damage is involved in the systolic dysfunction. Diastolic dysfunction precedes systolic dysfunction in the Ang IIinduced hypertensive model of HF [5], a model of pressure overload-induced HF. However, in the latter, mitochondrial damage accompanies the diastolic dysfunction. These data suggest that although the primary etiologic factor influences the impact of mitochondrial dysfunction on cardiac diastolic dysfunction, systolic dysfunction seems to develop in parallel with mitochondrial damage.

Taken together, the data we have reviewed here show that cardiac hypertrophy is associated with a similar increase in mitochondrial oxidative metabolism, and that mitochondrial dysfunction precedes or occurs in parallel with the development of HF. Definitive data to prove that mitochondrial dysfunction causes the transition from compensated cardiac hypertrophy to cardiac failure are lacking. However, mitochondrial-targeted strategies have proven to mitigate left ventricular dysfunction. For example, although hypertensive-induced hypertrophy does not induce changes in the ANT content and function, the overexpression of ANT ameliorated cardiac dysfunction in renin-overexpression cardiac hypertrophy [60]. Activation of mitochondrial energy metabolism by overexpression of the protein, frataxin, sustains the Akt survival pathway in cardiomyocytes through the insulin/IGF-1 receptor signaling and protects the heart from doxorubicin-induced cardiomyopathy [61]. Overexpression of mitochondrial catalase protects against mitochondrial dysfunction and cardiac hypertrophy, fibrosis, and failure induced by acute and chronic increase in reninangiotensin axis and mtDNA damage $[4,5]$. These data underscore a critical role of mitochondrial bioenergetics in cardiac hypertrophy and failure.

\section{B. Mechanisms for the transition from cardiac hypertrophy to failure}

\section{Hypertrophic signaling pathways}

Persistent cardiac hypertrophy in response to pathological signals is associated with increased risk for sudden death or progression to HF, irrespective of the initial cause of hypertrophy $[62,63]$. This observation suggests that cardiac hypertrophy, although considered adaptive, becomes maladaptive and leads to cardiac failure if prolonged. The significant clinical benefits of medications targeting the neuroendocrine hypertrophic signaling - $\beta$-blockers, angiotensin-converting enzyme inhibitors, angiotensin receptor blockers - on the clinical outcome of human subjects with HF support this concept of progression. It was recently shown that signaling pathways leading to cardiac hypertrophy and HF involve the participation of mitochondria $[4,5]$.

Adrenergic signals-The stimulation of the sympathetic adrenergic system plays a central role in the response of the heart to increased wall stress. Activation of $\beta$-adrenergic receptors ( $\beta-\mathrm{AR}$ ) increases the heart rate (chronotropy), contractility (inotropy), and relaxation speed (lusitropy). There are at least two major types of $\beta-A R$ in the heart, $\beta 1$-and $\beta 2-\mathrm{AR}$, which bind to heterotrimeric guanosine triphosphate binding proteins ( $\mathrm{G}$ proteins) and have different, even opposing, effects on gene expression, cell growth, and cell death. 
$\beta 1$-AR couple to the stimulatory G protein (Gs), activate adenylyl cyclase (AC) and increase cytosolic cAMP, which binds the regulatory subunits of protein kinase A (PKA) and releases the catalytic subunits (cPKA). cPKA mediates the increase in $\mathrm{Ca}^{2+}$ entry via L-type membrane $\mathrm{Ca}^{2+}$ channels and phosphorylates proteins involved in $\mathrm{Ca}^{2+}$ handling, such as phospholamban and the sarcoplasmic reticulum $\mathrm{Ca}^{2+}$-release channel called ryanodine receptor [64]. The net result of these events is an increase in cytosolic $\mathrm{Ca}^{2+}$ responsible for enhanced myofilament contraction.

In contrast, $\beta 2$-AR couple to both Gs and inhibitory $\mathrm{G}$ proteins in both murine [65] and human [66] myocardium. In the human heart, the $\beta 2$-AR effect on excitation-contraction coupling is also mediated by cAMP-PKA-dependent phosphorylation of proteins similar to $\beta 1$ stimulation. However, the $\beta 2$-AR-initiated cAMP signaling is limited to subsarcolemmal microdomains and modulates the sarcolemmal L-type $\mathrm{Ca}^{2+}$ channels, increasing $\mathrm{Ca}^{2+}$ entry [67]. By stimulating the Gi proteins, $\beta 2$-AR activation delivers cell survival signals to cardiomyocytes via stimulation of the phosphoinositide 3-kinase (PI3K)-Akt (protein kinase B)-glycogen synthase kinase-3ß-GATA4 (zinc finger transcription factor) pathway [68-71]. Also, stimulation of $\beta 1$-AR induces cardiomyocyte apoptosis [72]. In sharp contrast, $\beta 2$-AR stimulation does not cause cardiomyocyte hypertrophy and apoptosis, instead protecting cardiomyocytes against apoptosis induced by assaulting factors such as $\beta 1$-AR signaling and ROS [73].

The $\beta$-AR agonist, isoproterenol, causes cardiac hypertrophy in mammals [74] that is abolished by $\beta 1$ - but not by $\beta 2$-blockers [75]. The sustained $\beta$-AR activation with isoproterenol leads to enlargement of particular cardiomyocytes in parallel with myocyte loss, interstitial fibrosis, and inflammation. A rapid regression of cardiac hypertrophy occurs after cessation of isoproterenol administration, indicating that cardiac hypertrophy is reversible. Moreover, overexpression of components of the $\beta 1-G s-P K A$ pathway causes hypertrophy, deterioration of myocardial performance, and fibrosis [76-79] suggesting that the $\beta 1$-adrenergic stimulated hypertrophy is maladaptive. In support of this notion, $\beta$-blocker therapy has been shown to improve survival in HF patients [80-82].

A recent study shows that the inotropic response of cardiomyocytes to $\beta$-adrenergic stimulation-assessed as cytoplasmic $\mathrm{Ca}^{2+}$ transient amplitude and cell shortening-is mediated by mitochondrial ROS-generation in a PKA-cAMP-dependent manner [4]. When moderately $(\sim 25 \%)$ increased, the mitochondrial-released ROS induced by $\beta$-adrenergic stimulation act as second messengers to facilitate $\mathrm{Ca}^{2+}$ entry via plasma membrane L-type $\mathrm{Ca}^{2+}$ channels [4]. In contrast, a larger increase in mitochondrial ROS generation upon palmitate oxidation causes a decrease in $\mathrm{Ca}^{2+}$ transient amplitude and cardiomyocyte contractility associated with mitochondrial depolarization [83]. Moreover, the prolonged $\beta$ adrenergic stimulation (24 hours) also induces mitochondrial membrane depolarization and apoptosis $[84,85]$ that was inhibited by SOD and by catalase mimetics and catalase overexpression [85], indicating the involvement of $\beta$-adrenergic-simulated mitochondrial ROS as pro-apoptotic signals. Moreover, permeabilized rat cardiomyoctes stimulated with PKA catalytic subunit exhibit an increase in mitochondrial ROS generation and mitochondrial membrane depolarization [86]. Using saponin-permeabilized cardiac fibers, we found that pre-incubation with cAMP decreases mitochondrial oxidative phosphorylation due to a defect localized within the oxidation side of the pathway at complex IV inter alia of the ETC [87]. In contrast with cardiac fibers, isolated mitochondria are relatively insensitive to the effect of cAMP, suggesting that the cytosolic PKA anchored to the outer mitochondrial membrane is essential to mediate the inhibitory effect of extramitochondrialgenerated cAMP observed in cardiac fibers (unpublished observation). Activation of mitochondrial soluble adenylyl cyclase (AC) with bicarbonate causes a severe inhibition of mitochondrial oxidative phosphorylation (unpublished observation), suggesting that 
intramitochondrial-generated cAMP is inhibitory. Studies of the amount and activity of mitochondrial AC and its major activators—bicarbonate and calcium - should elucidate the pathophysiological significance of intramitochondrial-generated cAMP in HF.

In conclusion, mitochondrial-generated ROS are necessary members of the physiological $\beta$ adrenergic signaling pathway. They act as beneficial signaling molecules to transmit the inotropic effect of acute and limited adrenergic stimulation by a cAMP-PKA-dependent mechanism. Sustained activation of the mitochondrial cAMP-PKA pathway causes mitochondrial dysfunction, extensive mitochondrial-induced ROS production, decreased cardiomyocyte contractility, and apoptosis.

The mechanism responsible for the increase in mitochondrial ROS generation and mitochondrial damage upon activation of the $\beta$-adrenergic-PKA-cAMP pathway is unknown. In heart mitochondria isolated from HF, we found that complex IV unincorporated into the respirasomes exhibited an increased level of threonine phosphorylation [87], suggesting that cAMP-dependent phosphorylation of specific complex IV subunits either limits the incorporation of complex IV into supercomplexes or decreases supercomplex stability, leading to decreased oxidative phosphorylation [8]. We propose a sequential mechanistic pathway in which the increase in adrenergic drive as an initial adaptive event causes a decrease in functional respirasomes, leading to increased ROS generation and mitochondrial dysfunction. The cAMP generated by $\beta$-AR-linked sarcolemmal AC activates mitochondrial PKA, which phosphorylates threonine residues of complex IV protein subunits. These postranslational modifications impair the incorporation of complex IV into supercomplexes, reduce the amount of functional respirasomes, and decrease mitochondrial oxidative phosphorylation. These modifications result in decreased ATP generation and the accompanying energy deficit. Improper organization of ETC complexes in supramolecular assemblies also impedes electron channeling in the ETC, with an increase in electron leak and superoxide formation. Hydrogen peroxide-formed by superoxide dismutation--damages adjacent mitochondrial inner membrane proteins, including subunits of the ETC complexes. These oxidative alterations, which cause the decreased activity of ETC complexes reported by others in severe HF, potentially augment the severity of the energy deficit and oxidative stress.

The mechanism by which increased adrenergic stimulation affects mitochondrial function and leads to cardiac hypertrophy and failure is complex and may be independent of adrenergic receptors. For example, norepinephrine leads to cardiac hypertrophy through a mechanism independent of adrenergic receptor binding and mediated by monoamine oxidases (MAO) — outer mitochondrial membrane flavoenzymes responsible for the deamination of neurotransmitors generating hydrogen peroxide [1]. The expression of these enzymes is elevated in pathological heart hypertrophy and failure $[2,3]$ but is unchanged in exercise-induced physiological hypertrophy [2]. In addition, pharmacologic and genetic inhibition of MAO prevents cardiac oxidative stress and contractile dysfunction in mice under pressure-overload stress [1]. Cross-talk between MAO-generated oxidative stress and mitochondrial electron transport is suggested [4], which would lead to mitochondrial damage and amplification of oxidative stress in cardiomyocytes.

Alterations in ion homeostasis and excitation-contraction coupling in failing cardiomyocytes may cause oxidative stress and a decrease in $\mathrm{Ca}^{2+}$-dependent mitochondrial ATP production. For example, adrenergic stimulation causes an increased frequency and amplitude of cytosolic $\mathrm{Ca}^{2+}$ transients and an elevation in the steady state of mitochondrial $\mathrm{Ca}^{2+}[5]$. However, mitochondrial $\mathrm{Ca}^{2+}$ uptake is reported decreased in end-stage heart failure in human subjects [6] and cardiomyocytes upon adrenergic stimulation [7] leading to an increase in mitochondrial ROS generation [7]. 
Renin angiotensin system-Sustained $\beta$-AR activation is accompanied by increased angiotensin II (Ang II) concentrations in plasma and left ventricle [88], and increased circulating renin and aldosterone levels [88]. The local myocardial renin-angiotensin rather than systemic stimulation seems to be critical for cardiac hypertrophy, as shown by the preservation of left ventricle weight upon inhibition of kidney renin release [89].

Angiotensin II binds to angiotensin receptor-1, a Gq protein-coupled receptor, and induces cardiac hypertrophy. Moreover, animal models overexpressing Ang II downstream regulators develop cardiac hypertrophy with depressed contractile function[90, 91]. When the receptor is activated, the bound Gq protein dissociates into individual Gaq and GßY subunits. Gaq and GßY initiate a series of events that culminate with diacylglycerolmediated activation of protein kinase $\mathrm{C}$ (PKC) [92] and mitogen-activated protein kinase (MAPK) [93]. Activation of either PKC [94, 95] or MAPK [96] leads to a hypertrophic phenotype in cardiomyocytes.

Dai et al. recently showed that both the hypertrophic response induced by acute Ang II stimulation and the cardiac decompensation induced by persistent overexpression of Gaq are mediated by mitochondrial-generated ROS [5]. In these experiments, both Ang IIinduced cardiac hypertrophy and Gaq overexpression-induced cardiac failure are associated with a similar $(28 \%)$ decrease in mitochondrial function, oxidative changes of mitochondrial proteins, mitochondrial damage, and autophagy. Overexpression of mitochondrial catalase attenuated both heart hypertrophy and contractile dysfunction. The transition from cardiac hypertrophy to failure was marked by extensive modifications of mitochondrial DNA (mtDNA) and a profound decrease in mitochondrial biogenesis [5].

\section{Mitochondrial DNA}

Mitochondria have their own genome, mtDNA, which is a closed-circle double-stranded DNA molecule of $16.5 \mathrm{~Kb}$. mtDNA contains two promoters, the light-strand and the heavystrand promoters that initiate transcription to yield individual mRNAs encoding 13 subunits of the electron transport chain, 22 tRNAs and 2 rRNA subunits. The transcription from the light-strand promoter also produces RNA primer to initiate mtDNA replication. Therefore, mitochondrial function is directly dependent on mtDNA integrity, transcription and replication. In the heart, the frequency of mtDNA deletions was found to be correlated with mitochondrial dysfunction [97]. Human cardiomyopathies are associated with mtDNA mutations and deletions $[98,99]$. Karamanlidis et al. identified decreased replication and depletion of mtDNA as markers of the transition from compensated hypertrophy to right ventricular failure in children with congenital heart diseases [100]. Decreased mtDNA copy number is associated with myocardial remodeling and failure after myocardial infarction in mice [101]. Although connected, the causal relationship between abnormalities in mtDNA and cardiac failure has yet to be elucidated.

Primary mtDNA defects, such as point mutations or defective transcription, lead to inherited mitochondrial cardiomyopathies following the rules of heretoplasmy - the presence of both wild and mutated mtDNA within the same cell-and threshold effect—-the disease becomes apparent when the abnormal mtDNA reaches a certain tipping point. This leads to the idea that progressive alterations in mtDNA cause the transition from compensated hypertrophy to heart failure.

A similar degree of left ventricular hypertrophy is obtained upon administration of either Ang II or the antiviral drug, zidovudine-a nucleoside analog interfering with mtDNA replication fidelity - and in mice with defective exonuclease proofreading capacity due to a homozygous mutation of mitochondrial polymerase Y (Polg) [5]. Whereas Ang II treatment causes a decrease in mtDNA copy number and increase in mtDNA deletion frequency (4.3 fold) associated with cardiac hypertrophy with preserved systolic function, the use of the 
same treatment in Polg mice causes a dramatic increase in mtDNA deletion frequency (29fold), severe hypertrophy, and HF with impairment of both systolic and diastolic function, indicating that the severity of mtDNA mutations accelerates the progression from cardiac hypertrophy to HF [5]. These data highlight the fact that mtDNA depletion alone is sufficient to cause cardiac hypertrophy, as also observed in human patients [102]; the transition to HF seems to follow the threshold rule and is associated with severe mtDNA damage. Overexpression of mitochondrial catalase attenuated both the mtDNA mutation frequency and cardiac dysfunction, suggesting that mitochondrial -generated ROS are responsible for mtDNA damage [5].

Mitochondrial DNA also contains pro-inflammatory unmethylated CpG motifs [103, 104] and acts as damage-associated molecular pattern molecule when released from cardiac tissue in myocardial infarction and skeletal muscle in aseptic trauma patients [105, 106]. Damaged mitochondria are normally sequestered in autophagosomes that fuse with lysosomes, and are degraded. Because cardiac-specific impaired autophagy leads to cardiomyopathy in mice, constitutive autophagy is considered a homeostatic mechanism to maintain cardiac structure and function, and upregulation of autophagy in failing hearts is an adaptive mechanism to protect cardiomyocytes from hemodynamic stress [107]. Mitochondrial DNA that escape from the autophagic process was found to activate innate immunity and cause systemic inflammatory response syndrome, and trigger Toll-like receptor 9-mediated inflammation in cardiomyocytes, leading to myocarditis and dilated cardiomyopathy [108].

In conclusion, altered mtDNA or mtDNA released into the cytosol may accelerate the progression of compensated cardiac hypertrophy to HF by either leading to decreased mitochondrial bioenergetics or triggering cardiac inflammation.

\section{Biogenesis pathways}

Mitochondrial division is controlled by transcription of both mitochondrial and nuclear DNA, requires synthesis of new phospholipids and proteins, and is dependent on the fission process. The bidirectional communication between the nucleus and mitochondria is key to adjust mitochondrial bioenergetics to cellular homeostasis. Critical factors for mtDNA replication and transcription, which also regulate the synthesis of nuclear-encoded mitochondrial proteins necessary for mitochondrial biogenesis, consist of nuclear respiratory factors (NRF-1 and NRF-2), mitochondrial transcription factor A (TFAM), and nuclear receptor proteins including the peroxisome proliferator-activated receptors (PPARs). By increasing the transcriptional activity of NFRs on TFAM promoter and of PPARs, the PPAR gamma co-activators (PGC-1 $\alpha$ and $\beta$ ) are the master synchronizers of the two genomes. NFRs increase the expression of TFAM as well as the vast majority of nuclear-encoded subunits of the tricarboxylic acid cycle and ETC complexes. Mitochondrial transcription is initiated by the binding of the TFAM on an upstream enhancer of the two mtDNA strands. PGC-1 a controls optimal mitochondrial content, and its amount is directly correlated with mitochondrial density in both cardiac and skeletal muscle [109, 110]. Also, in healthy subjects, the expression level of PGC-1a, its downstream transcription factors, and mitochondrial proteins are linearly related to maximal oxygen consumption, indicating that PGC-1a is the key factor in determining energy generation capacity [111].

Studies with transgenic mice have shown that deficiencies in nuclear-encoded factors involved in mitochondrial biogenesis promote cardiomyopathy. For example, conditional cardiac-specific null TFAM allele in mice leads to a decreased mtDNA level and expression, progressive mitochondrial ETC defects, and HF [112], whereas systemic homozygous TFAM knockout strains show severe mtDNA depletion and bioenergetic demise, and die of cardiac failure during embryonic development [113]. In addition, the cardiac specific TFAM knockout mice exhibit an early genetic and metabolic switch, hindering fatty acid oxidation 
followed by mitochondrial proliferation and cardiac failure [15]. Both increased mitochondrial number and metabolic switch cannot compensate for the mitochondrial defect as shown by severe ATP depletion. In contrast, mice overexpressing TFAM are protected from developing mitochondrial damage and HF following myocardial infarction [114].

Jamshidi et al. found that a single nucleotide polymorphism in the PPARa gene independently predicted the degree of left ventricular hypertrophy induced by exercise in healthy volunteers [115], suggesting that PPARs play a major role in cardiac hypertrophy. Pathologic cardiac hypertrophy is associated with a suppression of fatty acid oxidation that is considered a metabolic adaptation for a lower oxygen consumption per ATP generated, and implies the demise of PPARs as regulators of fatty acid oxidation genes. Homozygous ablation of the PPARY gene causes embryonic lethality due to placental and cardiac defects [116], whereas heterozygous PPARY deficient mice exhibit an exaggerated cardiac hypertrophic response to pressure overload [117]. Barger et al. showed that PPARa is downregulated during pressure overload cardiac hypertrophy [118], whereas transgenic mice overexpressing PPARa exhibit cardiomyopathy [119], underscoring the critical role of proper expression of this transcription factor for the heart.

Polymorphisms in the PGC1a gene are correlated with an increased risk for hypertrophic cardiomopathy in human subjects [120]. PGC1 $\alpha$ and $\beta$ are expressed in highly-oxidative tissues including heart, and provide the transcriptional control of metabolic specific programs and mitochondrial biogenesis [121, 122]. PGC1a regulates the expression of nuclear genes encoding mitochondrial fatty acid oxidation enzymes [123] and the coordinated expression of both nuclear and mitochondrial genes encoding for mitochondrial proteins [124]. PGC-1a is considered a coordinator of acute metabolic adaptation, whereas PGC-1 $\beta$ maintains the mitochondrial biogenesis necessary to cover the basal energy requirement of the heart. PGC-1 $\beta$ deficiency induces decreased expression of genes encoding for mitochondrial oxidative phosphorylation components whereas fatty acid oxidation gene expression is preserved [125], indicating that the two PPAR co-activators play overlapping but also distinct roles in maintaining cardiac mitochondrial bioenergetics.

The general consensus from the literature is that mitochondrial biogenesis signals match the energy demand of the hypertrophic cardiomyocyte during compensated cardiac hypertrophy, but in HF these signals fail to keep pace with metabolic and structural remodeling and increased energy need (Figure 1). For example, PGC1 $\alpha$ and PGC1 $\beta$ are overexpressed at the stage of hypertrophy and return to normal levels at the stage of decompensation of the right ventricle in children with congenital heart diseases [100]. PGC1a, TFAM, NRF-1 and 2 expressions are increased in cardiac hypertrophy induced by either angiotensin II and AZT treatment or Polg deficiency in mice, and are decreased in cardiac failure [5]. In contrast, cardiac hypertrophy induced by transverse aortic constriction is associated with increased PGC- $1 \beta$ and decreased PGC1a expression, and decreased expression of oxidative phosphorylation and fatty acid oxidation genes [125]. In the same experimental model, the decompensated stage of heart failure is associated with a decrease of both PPAR coactivators [125], further depression in mitochondrial bioenergetics [22], and severe energy limitation [125].

PGC1a is considered responsible for the metabolic shift from fatty acid oxidation to glucose oxidation, which precedes cardiac decompensation [126]. This conclusion is in agreement with the observation that PGC1a knockout mice experience a decrease in mitochondrial fatty acid oxidation and oxidative phosphorylation with preserved cardiac function [127], whereas upon pressure-overload challenge they show oxidative stress and experience further decline in mitochondrial function that coincides with the transition to heart failure [126]. 
The lessons from these animal models lead to the conclusions that mitochondrial biogenesis signaling is preserved in early stages of compensated hypertrophy in order to match the increased energy need for enhanced workload. There is a critical threshold of mitochondrial metabolism necessary to keep pace with cardiac workload, and the transition to cardiac failure seems to be preceded or paralleled by a severe decrease in mitochondrial biogenesis and oxidative metabolism.

What are the mechanisms leading to changes in PGC1a expression and mitochondrial biogenesis? During both compensated hypertrophy and HF there is an adaptive adrenergic and renin-angiotensin stimulations shown to increase PGC1a expression. Also, signaling pathways that are upregulated in HF, such as MAPK and calcineurin signaling, activate the PGC1a pathways [128, 129]. Oxidative stress was found to increase the expression of both PGC1a and PGC1 $\beta$, as well as their promoter activity, leading to increase of mitochondrial electron transport expression genes, and mitochondrial and cytosolic ROS-detoxifying systems via a cAMP response element-dependent mechanism [130]. These data show the antioxidant role of PGC1a. Activation of the AMPK by energy deficit also induces PGC1a and PGC1 $\beta$ expression and mitochondrial biogenesis [131, 132]. Although the mechanisms leading to increased PGC expression in cardiac hypertrophy are understood, the molecular mechanisms responsible for the drop in PGC signaling upon the transition from compensated hypertrophy to HF are unidentified. In the face of short-term pressure-overload challenge, the heart can tolerate a complete absence of PGC1 $\beta$ and an approximate 50\% reduction in PGCla with relative preservation of left ventricular function [125], suggesting that additional factors induced by reduced expression of these transcriptional co-activators, such as oxidative stress, may lead to the transition of cardiac failure.

\section{Conclusions}

During compensated cardiac hypertrophy, the adaptive neuroendocrine signals induce hypertrophic and inotropic response in the heart via mitochondrial-generated ROS in order to maintain normal wall stress and cardiac output (Figure 2). This adaptation is associated with preserved or increased mitochondrial biogenesis signals and oxidative metabolism mediated by PGC1- $\alpha$ and - $\beta$ factors. Cardiac decompensation is accompanied by a decline in mitochondrial biogenesis signals and bioenergetics. Although mitochondrial -targeted strategies to improve bioenergetics have proven beneficial in mitigating cardiac dysfunction, the causal role of mitochondrial dysfunction in the progression from cardiac hypertrophy to failure has not been identified. We propose that prolonged systemic adrenergic stimulation ultimately leads to activation of the mitochondrial cAMP-PKA pathway leading to decreased mitochondrial respirasomes and oxidative phosphorylation, and mitochondrialgenerated oxidative stress. The resultant oxidative modifications of mitochondrial ETC complex protein subunits and mtDNA augment the decrease in mitochondrial oxidative metabolism associated with decline in mitochondrial biogenesis. The mechanism for the decrease in mitochondrial biogenesis signals including PGCs factors is unknown. The profound imbalance between energy demand and production leads to decreased myocardial contractile performance and cardiac output, which are markers of cardiac decompensation. In conclusion, therapeutic strategies to protect mitochondria against the maladaptive effect of neuroendocrine drives are required to prevent the transition from adaptive cardiac hypertrophy to cardiac failure.

\section{Acknowledgments}

Funding for this work was provided by the National Heart, Lung and Blood Institute, Program Project Grant PO1 (HL074237). 


\section{References}

1. McMurray JJ, Pfeffer MA. Heart failure. Lancet. 2005; 365(9474):1877-1889. May 28-Jun 3. [PubMed: 15924986]

2. Neubauer S. The failing heart--an engine out of fuel. The New England journal of medicine. 2007 Mar 15; 356(11):1140-1151. [PubMed: 17360992]

3. Dayer M, Cowie MR. Heart failure: diagnosis and healthcare burden. Clinical medicine (London, England). 2004 Jan-Feb;4(1):13-18.

4. Andersson DC, Fauconnier J, Yamada T, Lacampagne A, Zhang SJ, Katz A, et al. Mitochondrial production of reactive oxygen species contributes to the beta-adrenergic stimulation of mouse cardiomycytes. The Journal of physiology. 2011 Apr 1; 589(Pt 7):1791-1801. [PubMed: 21486840]

5. Dai DF, Johnson SC, Villarin JJ, Chin MT, Nieves-Cintron M, Chen T, et al. Mitochondrial oxidative stress mediates angiotensin II-induced cardiac hypertrophy and Galphaq overexpressioninduced heart failure. Circulation research. 2011 Apr 1; 108(7):837-846. [PubMed: 21311045]

6. Doenst T, Pytel G, Schrepper A, Amorim P, Farber G, Shingu Y, et al. Decreased rates of substrate oxidation ex vivo predict the onset of heart failure and contractile dysfunction in rats with pressure overload. Cardiovascular research. 2010 Jun 1; 86(3):461-470. [PubMed: 20035032]

7. Lindenmayer GE, Sordahl LA, Harigaya S, Allen JC, Besch HR Jr. Schwartz A. Some biochemical studies on subcellular systems isolated from fresh recipient human cardiac tissue obtained during transplantation. The American journal of cardiology. 1971 Mar; 27(3):277-283. [PubMed: 4250860]

8. Rosca MG, Vazquez EJ, Kerner J, Parland W, Chandler MP, Stanley W, et al. Cardiac mitochondria in heart failure: decrease in respirasomes and oxidative phosphorylation. Cardiovascular research. 2008 Oct 1; 80(1):30-39. [PubMed: 18710878]

9. Sharov VG, Goussev A, Lesch M, Goldstein S, Sabbah HN. Abnormal mitochondrial function in myocardium of dogs with chronic heart failure. Journal of molecular and cellular cardiology. 1998 Sep; 30(9):1757-1762. [PubMed: 9769231]

10. Sharov VG, Todor AV, Silverman N, Goldstein S, Sabbah HN. Abnormal mitochondrial respiration in failed human myocardium. Journal of molecular and cellular cardiology. 2000 Dec; 32(12):2361-2367. [PubMed: 11113011]

11. Sebastiani M, Giordano C, Nediani C, Travaglini C, Borchi E, Zani M, et al. Induction of mitochondrial biogenesis is a maladaptive mechanism in mitochondrial cardiomyopathies. Journal of the American College of Cardiology. 2007 Oct 2; 50(14):1362-1369. [PubMed: 17903636]

12. Graham BH, Waymire KG, Cottrell B, Trounce IA, MacGregor GR, Wallace DC. A mouse model for mitochondrial myopathy and cardiomyopathy resulting from a deficiency in the heart/muscle isoform of the adenine nucleotide translocator. Nature genetics. $1997 \mathrm{Jul}$; 16(3):226-234. [PubMed: 9207786]

13. Puccio H, Simon D, Cossee M, Criqui-Filipe P, Tiziano F, Melki J, et al. Mouse models for Friedreich ataxia exhibit cardiomyopathy, sensory nerve defect and Fe-S enzyme deficiency followed by intramitochondrial iron deposits. Nature genetics. $2001 \mathrm{Feb}$; 27(2):181-186. [PubMed: 11175786]

14. Li Y, Huang TT, Carlson EJ, Melov S, Ursell PC, Olson JL, et al. Dilated cardiomyopathy and neonatal lethality in mutant mice lacking manganese superoxide dismutase. Nature genetics. 1995 Dec; 11(4):376-381. [PubMed: 7493016]

15. Hansson A, Hance N, Dufour E, Rantanen A, Hultenby K, Clayton DA, et al. A switch in metabolism precedes increased mitochondrial biogenesis in respiratory chain-deficient mouse hearts. Proceedings of the National Academy of Sciences of the United States of America. 2004 Mar 2; 101(9):3136-3141. [PubMed: 14978272]

16. Shende P, Plaisance I, Morandi C, Pellieux C, Berthonneche C, Zorzato F, et al. Cardiac raptor ablation impairs adaptive hypertrophy, alters metabolic gene expression, and causes heart failure in mice. Circulation. 2011 Mar 15; 123(10):1073-1082. [PubMed: 21357822]

17. Iemitsu M, Miyauchi T, Maeda S, Sakai S, Fujii N, Miyazaki H, et al. Cardiac hypertrophy by hypertension and exercise training exhibits different gene expression of enzymes in energy metabolism. Hypertens Res. 2003 Oct; 26(10):829-837. [PubMed: 14621187] 
18. Nishio ML, Ornatsky OI, Craig EE, Hood DA. Mitochondrial biogenesis during pressure overload induced cardiac hypertrophy in adult rats. Canadian journal of physiology and pharmacology. 1995 May; 73(5):630-637. [PubMed: 7585330]

19. Garnier A, Fortin D, Delomenie C, Momken I, Veksler V, Ventura-Clapier R. Depressed mitochondrial transcription factors and oxidative capacity in rat failing cardiac and skeletal muscles. The Journal of physiology. 2003 Sep 1; 551(Pt 2):491-501. [PubMed: 12824444]

20. Scheubel RJ, Tostlebe M, Simm A, Rohrbach S, Prondzinsky R, Gellerich FN, et al. Dysfunction of mitochondrial respiratory chain complex I in human failing myocardium is not due to disturbed mitochondrial gene expression. Journal of the American College of Cardiology. 2002 Dec 18; 40(12):2174-2181. [PubMed: 12505231]

21. Griffiths ER, Friehs I, Scherr E, Poutias D, McGowan FX, Del Nido PJ. Electron transport chain dysfunction in neonatal pressure-overload hypertrophy precedes cardiomyocyte apoptosis independent of oxidative stress. The Journal of thoracic and cardiovascular surgery. 2010 Jun; 139(6):1609-1617. [PubMed: 20038480]

22. Dai DF, Hsieh EJ, Liu Y, Chen T, Beyer RP, Chin MT, et al. Mitochondrial proteome remodelling in pressure overload-induced heart failure: the role of mitochondrial oxidative stress. Cardiovascular research. 2012 Jan 1; 93(1):79-88. [PubMed: 22012956]

23. Bugger H, Schwarzer M, Chen D, Schrepper A, Amorim PA, Schoepe M, et al. Proteomic remodelling of mitochondrial oxidative pathways in pressure overload-induced heart failure. Cardiovascular research. 2010 Jan 15; 85(2):376-384. [PubMed: 19843514]

24. Jullig M, Hickey AJ, Chai CC, Skea GL, Middleditch MJ, Costa S, et al. Is the failing heart out of fuel or a worn engine running rich? A study of mitochondria in old spontaneously hypertensive rats. Proteomics. 2008 Jun; 8(12):2556-2572. [PubMed: 18563753]

25. Rosca MG, Hoppel CL. New aspects of impaired mitochondrial function in heart failure. Journal of bioenergetics and biomembranes. 2009 Apr; 41(2):107-112. [PubMed: 19347572]

26. Rosca MG, Hoppel CL. Mitochondria in heart failure. Cardiovascular research. 2010 Oct 1; 88(1): 40-50. [PubMed: 20668004]

27. Marin-Garcia J, Goldenthal MJ, Moe GW. Abnormal cardiac and skeletal muscle mitochondrial function in pacing-induced cardiac failure. Cardiovascular research. 2001 Oct; 52(1):103-110. [PubMed: 11557238]

28. Marin-Garcia J, Goldenthal MJ, Moe GW. Mitochondrial pathology in cardiac failure. Cardiovascular research. 2001 Jan; 49(1):17-26. [PubMed: 11121792]

29. Moe GW, Marin-Garcia J, Konig A, Goldenthal M, Lu X, Feng Q. In vivo TNF- alpha inhibition ameliorates cardiac mitochondrial dysfunction, oxidative stress, and apoptosis in experimental heart failure. American journal of physiology. 2004 Oct; 287(4):H1813-H1820. [PubMed: 15205165]

30. Jarreta D, Orus J, Barrientos A, Miro O, Roig E, Heras M, et al. Mitochondrial function in heart muscle from patients with idiopathic dilated cardiomyopathy. Cardiovascular research. 2000 Mar; 45(4):860-865. [PubMed: 10728411]

31. Ide T, Tsutsui H, Kinugawa S, Utsumi H, Kang D, Hattori N, et al. Mitochondrial electron transport complex I is a potential source of oxygen free radicals in the failing myocardium. Circulation research. 1999 Aug 20; 85(4):357-363. [PubMed: 10455064]

32. Buchwald A, Till H, Unterberg C, Oberschmidt R, Figulla HR, Wiegand V. Alterations of the mitochondrial respiratory chain in human dilated cardiomyopathy. European heart journal. 1990 Jun; 11(6):509-516. [PubMed: 2161769]

33. Sparagna GC, Chicco AJ, Murphy RC, Bristow MR, Johnson CA, Rees ML, et al. Loss of cardiac tetralinoleoyl cardiolipin in human and experimental heart failure. Journal of lipid research. 2007 Jul; 48(7):1559-1570. [PubMed: 17426348]

34. Quigley AF, Kapsa RM, Esmore D, Hale G, Byrne E. Mitochondrial respiratory chain activity in idiopathic dilated cardiomyopathy. Journal of cardiac failure. 2000 Mar; 6(1):47-55. [PubMed: 10746819]

35. Liu J, Wang C, Murakami Y, Gong G, Ishibashi Y, Prody C, et al. Mitochondrial ATPase and high-energy phosphates in failing hearts. American journal of physiology. $2001 \mathrm{Sep}$; 281(3):H1319-H1326. [PubMed: 11514303] 
36. McCutcheon LJ, Cory CR, Nowack L, Shen H, Mirsalami M, Lahucky R, et al. Respiratory chain defect of myocardial mitochondria in idiopathic dilated cardiomyopathy of Doberman pinscher dogs. Canadian journal of physiology and pharmacology. 1992 Nov; 70(11):1529-1533. [PubMed: 1338376]

37. Unverferth DV, Lee SW, Wallick ET. Human myocardial adenosine triphosphatase activities in health and heart failure. American heart journal. 1988 Jan; 115(1 Pt 1):139-146. [PubMed: 2827453]

38. Schultheiss HP. Dysfunction of the ADP/ATP carrier as a causative factor for the disturbance of the myocardial energy metabolism in dilated cardiomyopathy. Basic research in cardiology. 1992; 87(Suppl 1):311-320. [PubMed: 1497575]

39. Sylven C, Lin L, Jansson E, Sotonyi P, Fu LX, Waagstein F, et al. Ventricular adenine nucleotide translocator mRNA is upregulated in dilated cardiomyopathy. Cardiovascular research. $1993 \mathrm{Jul}$; 27(7):1295-1299. [PubMed: 8252591]

40. Dorner A, Schultheiss HP. The myocardial expression of the adenine nucleotide translocator isoforms is specifically altered in dilated cardiomyopathy. Herz. 2000 May; 25(3):176-180. [PubMed: 10904836]

41. Dorner A, Giessen S, Gaub R, Grosse Siestrup H, Schwimmbeck PL, Hetzer R, et al. An isoform shift in the cardiac adenine nucleotide translocase expression alters the kinetic properties of the carrier in dilated cardiomyopathy. Eur J Heart Fail. 2006 Jan; 8(1):81-89. [PubMed: 16107323]

42. Puchowicz MA, Varnes ME, Cohen BH, Friedman NR, Kerr DS, Hoppel CL. Oxidative phosphorylation analysis: assessing the integrated functional activity of human skeletal muscle mitochondria--case studies. Mitochondrion. 2004 Sep; 4(5-6):377-385. [PubMed: 16120399]

43. Faustin B, Rossignol R, Rocher C, Benard G, Malgat M, Letellier T. Mobilization of adenine nucleotide translocators as molecular bases of the biochemical threshold effect observed in mitochondrial diseases. The Journal of biological chemistry. 2004 May 7; 279(19):20411-20421. [PubMed: 14976187]

44. Rossignol R, Malgat M, Mazat JP, Letellier T. Threshold effect and tissue specificity. Implication for mitochondrial cytopathies. The Journal of biological chemistry. 1999 Nov 19; 274(47):3342633432. [PubMed: 10559224]

45. Groen AK, Wanders RJ, Westerhoff HV, van der Meer R, Tager JM. Quantification of the contribution of various steps to the control of mitochondrial respiration. The Journal of biological chemistry. 1982 Mar 25; 257(6):2754-2757. [PubMed: 7061448]

46. Gellerich FN, Bohnensack R, Kunz W. Control of mitochondrial respiration. The contribution of the adenine nucleotide translocator depends on the ATP- and ADP-consuming enzymes. Biochimica et biophysica acta. 1983 Feb 17; 722(2):381-391. [PubMed: 6301555]

47. Lemieux H, Semsroth S, Antretter H, Hofer D, Gnaiger E. Mitochondrial respiratory control and early defects of oxidative phosphorylation in the failing human heart. The international journal of biochemistry \& cell biology. 2011 Dec; 43(12):1729-1738. [PubMed: 21871578]

48. Villani G, Attardi G. In vivo control of respiration by cytochrome c oxidase in human cells. Free radical biology \& medicine. 2000 Aug; 29(3-4):202-210. [PubMed: 11035248]

49. Kadenbach B, Huttemann M, Arnold S, Lee I, Bender E. Mitochondrial energy metabolism is regulated via nuclear-coded subunits of cytochrome c oxidase. Free radical biology \& medicine. 2000 Aug; 29(3-4):211-221. [PubMed: 11035249]

50. Sordahl LA, McCollum WB, Wood WG, Schwartz A. Mitochondria and sarcoplasmic reticulum function in cardiac hypertrophy and failure. The American journal of physiology. 1973 Mar; 224(3):497-502. [PubMed: 4266238]

51. Gong G, Liu J, Liang P, Guo T, Hu Q, Ochiai K, et al. Oxidative capacity in failing hearts. American journal of physiology. 2003 Aug; 285(2):H541-H548. [PubMed: 12714322]

52. Sanbe A, Tanonaka K, Niwano Y, Takeo S. Improvement of cardiac function and myocardial energy metabolism of rats with chronic heart failure by long-term coenzyme Q10 treatment. The Journal of pharmacology and experimental therapeutics. 1994 Apr; 269(1):51-56. [PubMed: 8169851] 
53. Palmer JW, Tandler B, Hoppel CL. Biochemical properties of subsarcolemmal and interfibrillar mitochondria isolated from rat cardiac muscle. The Journal of biological chemistry. 1977 Dec 10; 252(23):8731-8739. [PubMed: 925018]

54. Palmer JW, Tandler B, Hoppel CL. Biochemical differences between subsarcolemmal and interfibrillar mitochondria from rat cardiac muscle: effects of procedural manipulations. Archives of biochemistry and biophysics. 1985 Feb 1; 236(2):691-702. [PubMed: 2982322]

55. Lindenmayer GE, Sordahl LA, Schwartz A. Reevaluation of oxidative phosphorylation in cardiac mitochondria from normal animals and animals in heart failure. Circulation research. 1968 Sep; 23(3):439-450. [PubMed: 5676454]

56. Hoppel CL, Tandler B, Parland W, Turkaly JS, Albers LD. Hamster cardiomyopathy. A defect in oxidative phosphorylation in the cardiac interfibrillar mitochondria. The Journal of biological chemistry. 1982 Feb 10; 257(3):1540-1548. [PubMed: 6460026]

57. Lindenmayer GE, Harigaya S, Bajusz E, Schwartz A. Oxidative phosphorylation and calcium transport of mitochondria isolated from cardiomyopathic hamster hearts. Journal of molecular and cellular cardiology. 1970 Sep; 1(3):249-259. [PubMed: 5519939]

58. Wrogemann K, Blanchaer MC, Jacobson BE. Oxidative phosphorylation in cardiomyopathic hamsters. The American journal of physiology. 1972 Jun; 222(6):1453-1457. [PubMed: 5030202]

59. Abel ED, Doenst T. Mitochondrial adaptations to physiological vs. pathological cardiac hypertrophy. Cardiovascular research. 2011 May 1; 90(2):234-242. [PubMed: 21257612]

60. Walther T, Tschope C, Sterner-Kock A, Westermann D, Heringer-Walther S, Riad A, et al. Accelerated mitochondrial adenosine diphosphate/adenosine triphosphate transport improves hypertension-induced heart disease. Circulation. 2007 Jan 23; 115(3):333-344. [PubMed: 17210842]

61. Schulz TJ, Westermann D, Isken F, Voigt A, Laube B, Thierbach R, et al. Activation of mitochondrial energy metabolism protects against cardiac failure. Aging. 2010 Nov; 2(11):843853. [PubMed: 21084725]

62. Levy D, Garrison RJ, Savage DD, Kannel WB, Castelli WP. Prognostic implications of echocardiographically determined left ventricular mass in the Framingham Heart Study. The New England journal of medicine. 1990 May 31; 322(22):1561-1566. [PubMed: 2139921]

63. Haider AW, Larson MG, Benjamin EJ, Levy D. Increased left ventricular mass and hypertrophy are associated with increased risk for sudden death. Journal of the American College of Cardiology. 1998 Nov; 32(5):1454-1459. [PubMed: 9809962]

64. Bers DM. Cardiac excitation-contraction coupling. Nature. 2002 Jan 10; 415(6868):198-205. [PubMed: 11805843]

65. Xiao RP, Avdonin P, Zhou YY, Cheng H, Akhter SA, Eschenhagen T, et al. Coupling of beta2adrenoceptor to Gi proteins and its physiological relevance in murine cardiac myocytes. Circulation research. 1999 Jan 8-22; 84(1):43-52. [PubMed: 9915773]

66. Kilts JD, Gerhardt MA, Richardson MD, Sreeram G, Mackensen GB, Grocott HP, et al. Beta(2)adrenergic and several other $\mathrm{G}$ protein-coupled receptors in human atrial membranes activate both G(s) and G(i). Circulation research. 2000 Oct 13; 87(8):705-709. [PubMed: 11029407]

67. Xiao RP, Lakatta EG. Beta 1-adrenoceptor stimulation and beta 2-adrenoceptor stimulation differ in their effects on contraction, cytosolic $\mathrm{Ca} 2+$, and $\mathrm{Ca} 2+$ current in single rat ventricular cells. Circulation research. 1993 Aug; 73(2):286-300. [PubMed: 8101141]

68. Chesley A, Lundberg MS, Asai T, Xiao RP, Ohtani S, Lakatta EG, et al. The beta(2)-adrenergic receptor delivers an antiapoptotic signal to cardiac myocytes through $\mathrm{G}(\mathrm{i})$-dependent coupling to phosphatidylinositol 3'-kinase. Circulation research. 2000 Dec 8; 87(12):1172-1179. [PubMed: 11110775]

69. Zhu WZ, Zheng M, Koch WJ, Lefkowitz RJ, Kobilka BK, Xiao RP. Dual modulation of cell survival and cell death by beta(2)-adrenergic signaling in adult mouse cardiac myocytes. Proceedings of the National Academy of Sciences of the United States of America. 2001 Feb 13; 98(4):1607-1612. [PubMed: 11171998]

70. Morisco C, Seta K, Hardt SE, Lee Y, Vatner SF, Sadoshima J. Glycogen synthase kinase 3beta regulates GATA4 in cardiac myocytes. The Journal of biological chemistry. $2001 \mathrm{Jul}$ 27; 276(30): 28586-28597. [PubMed: 11382772] 
71. Morisco C, Zebrowski D, Condorelli G, Tsichlis P, Vatner SF, Sadoshima J. The Akt-glycogen synthase kinase 3beta pathway regulates transcription of atrial natriuretic factor induced by betaadrenergic receptor stimulation in cardiac myocytes. The Journal of biological chemistry. 2000 May 12; 275(19):14466-14475. [PubMed: 10799529]

72. Communal C, Singh K, Pimentel DR, Colucci WS. Norepinephrine stimulates apoptosis in adult rat ventricular myocytes by activation of the beta-adrenergic pathway. Circulation. 1998 Sep 29; 98(13):1329-1334. [PubMed: 9751683]

73. Communal C, Singh K, Sawyer DB, Colucci WS. Opposing effects of beta(1)- and beta(2)adrenergic receptors on cardiac myocyte apoptosis : role of a pertussis toxin-sensitive $\mathrm{G}$ protein. Circulation. 1999 Nov 30; 100(22):2210-2212. [PubMed: 10577992]

74. Alderman EL, Harrison DC. Myocardial hypertrophy resulting from low dosage isoproterenol administration in rats. Proceedings of the Society for Experimental Biology and Medicine Society for Experimental Biology and Medicine (New York, NY. 1971 Jan; 136(1):268-270.

75. Morisco C, Zebrowski DC, Vatner DE, Vatner SF, Sadoshima J. Beta-adrenergic cardiac hypertrophy is mediated primarily by the beta(1)-subtype in the rat heart. Journal of molecular and cellular cardiology. 2001 Mar; 33(3):561-573. [PubMed: 11181023]

76. Engelhardt S, Hein L, Keller U, Klambt K, Lohse MJ. Inhibition of $\mathrm{Na}(+)-\mathrm{H}(+)$ exchange prevents hypertrophy, fibrosis, and heart failure in beta(1)-adrenergic receptor transgenic mice. Circulation research. 2002 Apr 19; 90(7):814-819. [PubMed: 11964375]

77. Bisognano JD, Weinberger HD, Bohlmeyer TJ, Pende A, Raynolds MV, Sastravaha A, et al. Myocardial-directed overexpression of the human beta(1)-adrenergic receptor in transgenic mice. Journal of molecular and cellular cardiology. 2000 May; 32(5):817-830. [PubMed: 10775486]

78. Gaudin C, Ishikawa Y, Wight DC, Mahdavi V, Nadal-Ginard B, Wagner TE, et al. Overexpression of Gs alpha protein in the hearts of transgenic mice. The Journal of clinical investigation. 1995 Apr; 95(4):1676-1683. [PubMed: 7706476]

79. Antos CL, Frey N, Marx SO, Reiken S, Gaburjakova M, Richardson JA, et al. Dilated cardiomyopathy and sudden death resulting from constitutive activation of protein kinase a. Circulation research. 2001 Nov 23; 89(11):997-1004. [PubMed: 11717156]

80. Packer M, Bristow MR, Cohn JN, Colucci WS, Fowler MB, Gilbert EM, et al. The effect of carvedilol on morbidity and mortality in patients with chronic heart failure. U.S. Carvedilol Heart Failure Study Group. The New England journal of medicine. 1996 May 23; 334(21):1349-1355. [PubMed: 8614419]

81. Effect of metoprolol CR/XL in chronic heart failure: Metoprolol CR/XL Randomised Intervention Trial in Congestive Heart Failure (MERIT-HF). Lancet. 1999 Jun 12; 353(9169):2001-2007. [PubMed: 10376614]

82. The Cardiac Insufficiency Bisoprolol Study II (CIBIS-II): a randomised trial. Lancet. 1999 Jan 2; 353(9146):9-13. [PubMed: 10023943]

83. Fauconnier J, Andersson DC, Zhang SJ, Lanner JT, Wibom R, Katz A, et al. Effects of palmitate on $\mathrm{Ca}(2+)$ handling in adult control and ob/ob cardiomyocytes: impact of mitochondrial reactive oxygen species. Diabetes. 2007 Apr; 56(4):1136-1142. [PubMed: 17229941]

84. Menon B, Singh M, Ross RS, Johnson JN, Singh K. beta-Adrenergic receptor- stimulated apoptosis in adult cardiac myocytes involves MMP-2-mediated disruption of beta1 integrin signaling and mitochondrial pathway. Am J Physiol Cell Physiol. 2006 Jan; 290(1):C254-C261. [PubMed: 16148033]

85. Remondino A, Kwon SH, Communal C, Pimentel DR, Sawyer DB, Singh K, et al. Beta-adrenergic receptor-stimulated apoptosis in cardiac myocytes is mediated by reactive oxygen species/c-Jun NH2-terminal kinase-dependent activation of the mitochondrial pathway. Circulation research. 2003 Feb 7; 92(2):136-138. [PubMed: 12574140]

86. Nagasaka S, Katoh H, Niu CF, Matsui S, Urushida T, Satoh H, et al. Protein kinase A catalytic subunit alters cardiac mitochondrial redox state and membrane potential via the formation of reactive oxygen species. Circ J. 2007 Mar; 71(3):429-436. [PubMed: 17322647]

87. Rosca M, Minkler P, Hoppel CL. Cardiac mitochondria in heart failure: normal cardiolipin profile and increased threonine phosphorylation of complex IV. Biochimica et biophysica acta. 2011 Nov; 1807(11):1373-1382. [PubMed: 21320465] 
88. Grimm D, Holmer SR, Riegger GA, Kromer EP. Effects of beta-receptor blockade and angiotensin II type I receptor antagonism in isoproterenol-induced heart failure in the rat. Cardiovasc Pathol. 1999 Nov-Dec;8(6):315-323. [PubMed: 10615017]

89. Nagano M, Higaki J, Nakamura F, Higashimori K, Nagano N, Mikami H, et al. Role of cardiac angiotensin II in isoproterenol-induced left ventricular hypertrophy. Hypertension. 1992 Jun; 19(6 Pt 2):708-712. [PubMed: 1534315]

90. D'Angelo DD, Sakata Y, Lorenz JN, Boivin GP, Walsh RA, Liggett SB, et al. Transgenic Galphaq overexpression induces cardiac contractile failure in mice. Proceedings of the National Academy of Sciences of the United States of America. 1997 Jul 22; 94(15):8121-8126. [PubMed: 9223325]

91. Sakata Y, Hoit BD, Liggett SB, Walsh RA, Dorn GW 2nd. Decompensation of pressure-overload hypertrophy in G alpha q-overexpressing mice. Circulation. 1998 Apr 21; 97(15):1488-1495. [PubMed: 9576430]

92. Nishizuka Y. Turnover of inositol phospholipids and signal transduction. Science (New York, NY. 1984 Sep 21; 225(4668):1365-1370.

93. van Biesen T, Hawes BE, Luttrell DK, Krueger KM, Touhara K, Porfiri E, et al. Receptor-tyrosinekinase- and $\mathrm{G}$ beta gamma-mediated MAP kinase activation by a common signalling pathway. Nature. 1995 Aug 31; 376(6543):781-784. [PubMed: 7651538]

94. Allo SN, McDermott PJ, Carl LL, Morgan HE. Phorbol ester stimulation of protein kinase C activity and ribosomal DNA transcription. Role in hypertrophic growth of cultured cardiomyocytes. The Journal of biological chemistry. 1991 Nov 15; 266(32):22003-22009. [PubMed: 1939221]

95. McDermott PJ, Carl LL, Conner KJ, Allo SN. Transcriptional regulation of ribosomal RNA synthesis during growth of cardiac myocytes in culture. The Journal of biological chemistry. 1991 Mar 5; 266(7):4409-4416. [PubMed: 1999424]

96. Gillespie-Brown J, Fuller SJ, Bogoyevitch MA, Cowley S, Sugden PH. The mitogen-activated protein kinase kinase MEK1 stimulates a pattern of gene expression typical of the hypertrophic phenotype in rat ventricular cardiomyocytes. The Journal of biological chemistry. 1995 Nov 24; 270(47):28092-28096. [PubMed: 7499296]

97. Vermulst M, Wanagat J, Kujoth GC, Bielas JH, Rabinovitch PS, Prolla TA, et al. DNA deletions and clonal mutations drive premature aging in mitochondrial mutator mice. Nature genetics. 2008 Apr; 40(4):392-394. [PubMed: 18311139]

98. Corral-Debrinski M, Shoffner JM, Lott MT, Wallace DC. Association of mitochondrial DNA damage with aging and coronary atherosclerotic heart disease. Mutation research. 1992 Sep; 275(3-6):169-180. [PubMed: 1383759]

99. Arbustini E, Diegoli M, Fasani R, Grasso M, Morbini P, Banchieri N, et al. Mitochondrial DNA mutations and mitochondrial abnormalities in dilated cardiomyopathy. The American journal of pathology. 1998 Nov; 153(5):1501-1510. [PubMed: 9811342]

100. Karamanlidis G, Bautista-Hernandez V, Fynn-Thompson F, Del Nido P, Tian R. Impaired mitochondrial biogenesis precedes heart failure in right ventricular hypertrophy in congenital heart disease. Circ Heart Fail. 2011 Nov; 4(6):707-713. [PubMed: 21840936]

101. Ide T, Tsutsui H, Hayashidani S, Kang D, Suematsu N, Nakamura K, et al. Mitochondrial DNA damage and dysfunction associated with oxidative stress in failing hearts after myocardial infarction. Circulation research. 2001 Mar 16; 88(5):529-535. [PubMed: 11249877]

102. Anan R, Nakagawa M, Miyata M, Higuchi I, Nakao S, Suehara M, et al. Cardiac involvement in mitochondrial diseases. A study on 17 patients with documented mitochondrial DNA defects. Circulation. 1995 Feb 15; 91(4):955-961. [PubMed: 7850981]

103. Pollack Y, Kasir J, Shemer R, Metzger S, Szyf M. Methylation pattern of mouse mitochondrial DNA. Nucleic acids research. 1984 Jun 25; 12(12):4811-4824. [PubMed: 6330684]

104. Collins LV, Hajizadeh S, Holme E, Jonsson IM, Tarkowski A. Endogenously oxidized mitochondrial DNA induces in vivo and in vitro inflammatory responses. Journal of leukocyte biology. 2004 Jun; 75(6):995-1000. [PubMed: 14982943]

105. Raoof M, Zhang Q, Itagaki K, Hauser CJ. Mitochondrial peptides are potent immune activators that activate human neutrophils via FPR-1. The Journal of trauma. 2010 Jun; 68(6):1328-1332. discussion 32-4. [PubMed: 20539176] 
106. Zhang Q, Raoof M, Chen Y, Sumi Y, Sursal T, Junger W, et al. Circulating mitochondrial DAMPs cause inflammatory responses to injury. Nature. 2010 Mar 4; 464(7285):104-107. [PubMed: 20203610]

107. Nakai A, Yamaguchi O, Takeda T, Higuchi Y, Hikoso S, Taniike M, et al. The role of autophagy in cardiomyocytes in the basal state and in response to hemodynamic stress. Nature medicine. 2007 May; 13(5):619-624.

108. Oka T, Hikoso S, Yamaguchi O, Taneike M, Takeda T, Tamai T, et al. Mitochondrial DNA that escapes from autophagy causes inflammation and heart failure. Nature. 2012 May 10; 485(7397): 251-255. [PubMed: 22535248]

109. Lai L, Leone TC, Zechner C, Schaeffer PJ, Kelly SM, Flanagan DP, et al. Transcriptional coactivators PGC-1alpha and PGC-lbeta control overlapping programs required for perinatal maturation of the heart. Genes \& development. 2008 Jul 15; 22(14):1948-1961. [PubMed: 18628400]

110. Lehman JJ, Barger PM, Kovacs A, Saffitz JE, Medeiros DM, Kelly DP. Peroxisome proliferatoractivated receptor gamma coactivator-1 promotes cardiac mitochondrial biogenesis. The Journal of clinical investigation. 2000 Oct; 106(7):847-856. [PubMed: 11018072]

111. Garnier A, Fortin D, Zoll J, N'Guessan B, Mettauer B, Lampert E, et al. Coordinated changes in mitochondrial function and biogenesis in healthy and diseased human skeletal muscle. Faseb J. 2005 Jan; 19(1):43-52. [PubMed: 15629894]

112. Wang J, Wilhelmsson H, Graff C, Li H, Oldfors A, Rustin P, et al. Dilated cardiomyopathy and atrioventricular conduction blocks induced by heart-specific inactivation of mitochondrial DNA gene expression. Nature genetics. 1999 Jan; 21(1):133-137. [PubMed: 9916807]

113. Larsson NG, Wang J, Wilhelmsson H, Oldfors A, Rustin P, Lewandoski M, et al. Mitochondrial transcription factor A is necessary for mtDNA maintenance and embryogenesis in mice. Nature genetics. 1998 Mar; 18(3):231-236. [PubMed: 9500544]

114. Ikeuchi M, Matsusaka H, Kang D, Matsushima S, Ide T, Kubota T, et al. Overexpression of mitochondrial transcription factor a ameliorates mitochondrial deficiencies and cardiac failure after myocardial infarction. Circulation. 2005 Aug 2; 112(5):683-690. [PubMed: 16043643]

115. Jamshidi Y, Montgomery HE, Hense HW, Myerson SG, Torra IP, Staels B, et al. Peroxisome proliferator--activated receptor alpha gene regulates left ventricular growth in response to exercise and hypertension. Circulation. 2002 Feb 26; 105(8):950-955. [PubMed: 11864924]

116. Barak Y, Nelson MC, Ong ES, Jones YZ, Ruiz-Lozano P, Chien KR, et al. PPAR gamma is required for placental, cardiac, and adipose tissue development. Molecular cell. 1999 Oct; 4(4): 585-595. [PubMed: 10549290]

117. Asakawa M, Takano H, Nagai T, Uozumi H, Hasegawa H, Kubota N, et al. Peroxisome proliferator-activated receptor gamma plays a critical role in inhibition of cardiac hypertrophy in vitro and in vivo. Circulation. 2002 Mar 12; 105(10):1240-1246. [PubMed: 11889020]

118. Barger PM, Brandt JM, Leone TC, Weinheimer CJ, Kelly DP. Deactivation of peroxisome proliferator-activated receptor-alpha during cardiac hypertrophic growth. The Journal of clinical investigation. 2000 Jun; 105(12):1723-1730. [PubMed: 10862787]

119. Finck BN, Lehman JJ, Leone TC, Welch MJ, Bennett MJ, Kovacs A, et al. The cardiac phenotype induced by PPARalpha overexpression mimics that caused by diabetes mellitus. The Journal of clinical investigation. 2002 Jan; 109(1):121-130. [PubMed: 11781357]

120. Wang S, Fu C, Wang H, Shi Y, Xu X, Chen J, et al. Polymorphisms of the peroxisome proliferator-activated receptor-gamma coactivator-1alpha gene are associated with hypertrophic cardiomyopathy and not with hypertension hypertrophy. Clin Chem Lab Med. 2007; 45(8):962967. [PubMed: 17579564]

121. Puigserver P, Wu Z, Park CW, Graves R, Wright M, Spiegelman BM. A cold-inducible coactivator of nuclear receptors linked to adaptive thermogenesis. Cell. 1998 Mar 20; 92(6):829_ 839. [PubMed: 9529258]

122. Meirhaeghe A, Crowley V, Lenaghan C, Lelliott C, Green K, Stewart A, et al. Characterization of the human, mouse and rat PGC1 beta (peroxisome-proliferator-activated receptor-gamma coactivator 1 beta) gene in vitro and in vivo. The Biochemical journal. 2003 Jul 1; 373(Pt 1):155165. [PubMed: 12678921] 
123. Vega RB, Huss JM, Kelly DP. The coactivator PGC-1 cooperates with peroxisome proliferatoractivated receptor alpha in transcriptional control of nuclear genes encoding mitochondrial fatty acid oxidation enzymes. Molecular and cellular biology. 2000 Mar; 20(5):1868-1876. [PubMed: 10669761]

124. Wu Z, Puigserver P, Andersson U, Zhang C, Adelmant G, Mootha V, et al. Mechanisms controlling mitochondrial biogenesis and respiration through the thermogenic coactivator PGC-1. Cell. 1999 Jul 9; 98(1):115-124. [PubMed: 10412986]

125. Riehle C, Wende AR, Zaha VG, Pires KM, Wayment B, Olsen C, et al. PGC-1beta deficiency accelerates the transition to heart failure in pressure overload hypertrophy. Circulation research. 2011 Sep 16; 109(7):783-793. [PubMed: 21799152]

126. Arany Z, Novikov M, Chin S, Ma Y, Rosenzweig A, Spiegelman BM. Transverse aortic constriction leads to accelerated heart failure in mice lacking PPAR-gamma coactivator 1alpha. Proceedings of the National Academy of Sciences of the United States of America. 2006 Jun 27; 103(26):10086-10091. [PubMed: 16775082]

127. Lehman JJ, Boudina S, Banke NH, Sambandam N, Han X, Young DM, et al. The transcriptional coactivator PGC-1alpha is essential for maximal and efficient cardiac mitochondrial fatty acid oxidation and lipid homeostasis. American journal of physiology. 2008 Jul; 295(1):H185-H196. [PubMed: 18487436]

128. Gundewar S, Calvert JW, Jha S, Toedt-Pingel I, Ji SY, Nunez D, et al. Activation of AMPactivated protein kinase by metformin improves left ventricular function and survival in heart failure. Circulation research. 2009 Feb 13; 104(3):403-411. [PubMed: 19096023]

129. Tian R, Musi N, D'Agostino J, Hirshman MF, Goodyear LJ. Increased adenosine monophosphateactivated protein kinase activity in rat hearts with pressure-overload hypertrophy. Circulation. 2001 Oct 2; 104(14):1664-1669. [PubMed: 11581146]

130. St-Pierre J, Drori S, Uldry M, Silvaggi JM, Rhee J, Jager S, et al. Suppression of reactive oxygen species and neurodegeneration by the PGC-1 transcriptional coactivators. Cell. 2006 Oct 20; 127(2):397-408. [PubMed: 17055439]

131. Rohas LM, St-Pierre J, Uldry M, Jager S, Handschin C, Spiegelman BM. A fundamental system of cellular energy homeostasis regulated by PGC-1alpha. Proceedings of the National Academy of Sciences of the United States of America. 2007 May 8; 104(19):7933-7938. [PubMed: 17470778]

132. Kahn BB, Alquier T, Carling D, Hardie DG. AMP-activated protein kinase: ancient energy gauge provides clues to modern understanding of metabolism. Cell metabolism. 2005 Jan; 1(1):15-25. [PubMed: 16054041]

133. Dorner A, Pauschinger M, Schwimmbeck PL, Kuhl U, Schultheiss HP. The shift in the myocardial adenine nucleotide translocator isoform expression pattern is associated with an enteroviral infection in the absence of an active T-cell dependent immune response in human inflammatory heart disease. Journal of the American College of Cardiology. 2000 Jun; 35(7): 1778-1784. [PubMed: 10841224]

134. Schultheiss HP, Bolte HD. Immunological analysis of auto-antibodies against the adenine nucleotide translocator in dilated cardiomyopathy. Journal of molecular and cellular cardiology. 1985 Jun; 17(6):603-617. [PubMed: 2991541]

135. Shinde SB, Save VC, Patil ND, Mishra KP, Tendolkar AG. Impairment of mitochondrial respiratory chain enzyme activities in tetralogy of Fallot. Clinica chimica acta; international journal of clinical chemistry. 2007 Feb; 377(1-2):138-143. 


\section{Highlights}

- mitochondrial-ROS mediates the adrenergic-induced cardiac adaptation in pathological cardiac hypertrophy

- cardiac adaptation is associated with preserved mitochondrial biogenesis

- decline in mitochondrial biogenesis and bioenergetics marks the transition to cardiac decompensation

- bioenergetic failure is mediated by prolonged adrenergic-induced cAMP-PKA pathway 
Hypertrophic signals

\section{mtDNA}

Bioenergetic signals

Mitochondrial content

ETC complexes amount ETC complexes
activity

\section{Oxidative phosphorylation}

Trigger Compensated hypertrophy

Figure 1.

The progression of biochemical features during the transition from cardiac hypertrophy to heart failure 


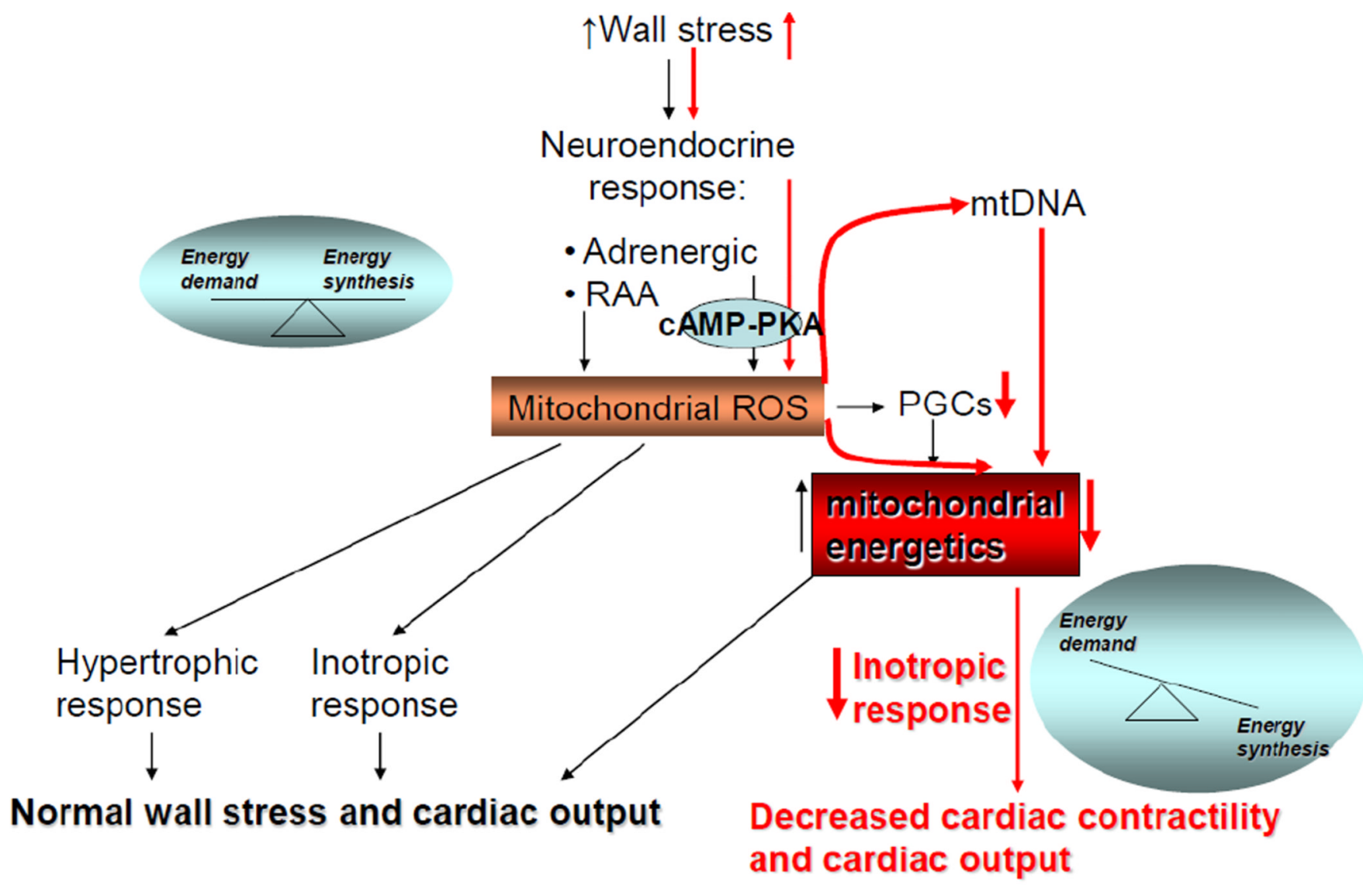

Compensated hypertrophy

Heart Failure

Figure 2.

Molecular mechanisms responsible for cardiac hypertrophy and failure 


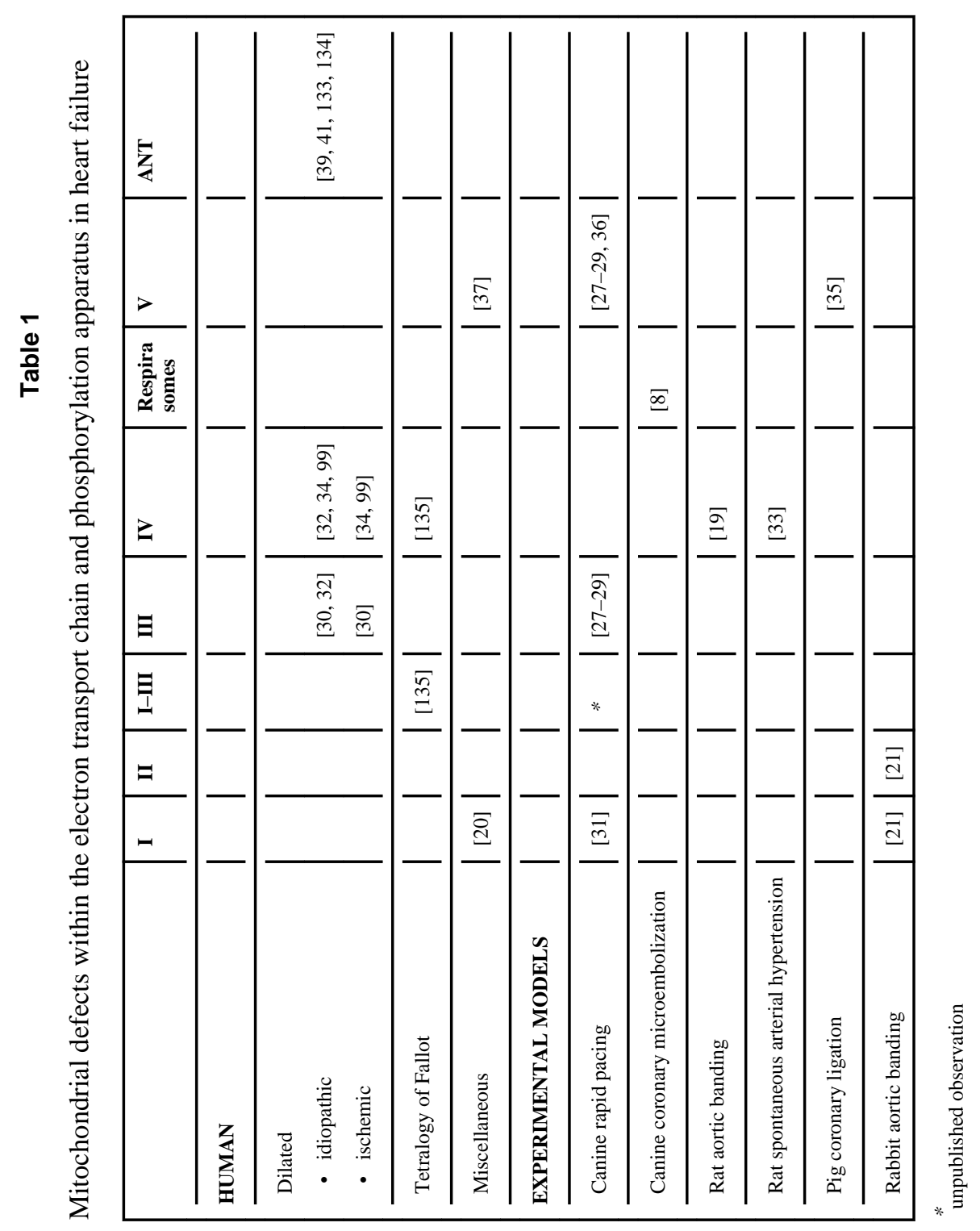

J Mol Cell Cardiol. Author manuscript; available in PMC 2014 February 01. 